Sri Lanka J. Aquat. Sci. 12 (2007): 61-75

\title{
Accumulation of heavy metals in a food fish, Mystus gulio inhabiting Bolgoda Lake, Sri Lanka
}

\author{
P. SENARATHNE AND K. A. S. PATHIRATNE ${ }^{*}$ \\ ${ }^{1}$ Pollution Control Division, Ministry of Environment and Natural Resources, \\ Baththaramulla, Sri Lanka. \\ ${ }^{2}$ Department of Chemistry, University of Kelaniya, Kelaniya, Sri Lanka. \\ *Corresponding author (E-mail : kaspathi@kln.ac.lk)
}

\begin{abstract}
Bioaccumulation potential of selected heavy metalsviz. $\mathrm{Pb}, \mathrm{Cd}, \mathrm{Cr}$, $\mathrm{Cu}$, and $\mathrm{Zn}$ in muscle, gills and liver of food fish, Mystus gulio (Anguluwa) inhabiting in Bolgoda Lake were assessed by analyzing metal levels in the fish collected from four main locations: W eras Ganga, North Lake, Bolgoda Ganga and South Lake. In addition, water and sediment samples were taken concurrently from the sampling locations for determination of the metal levels. The metal levels were analysed by atomic absorption spectrometry using standard procedures. Dissolved total metal levels in lake water (in $\mu \mathrm{g}$ $\mathrm{L}^{-1}$ ) varied depending on the sampling location: $\mathrm{Pb}$ 23.2-36.3, $\mathrm{Cd}$ 6.1-12.6, $\mathrm{Cr}$ 3.9-61.4, $\mathrm{Cu}$ 5.7-38, and $\mathrm{Zn} 11.6-35.1$. The sediment associated metals in the lake (in $\mu \mathrm{g} \mathrm{g}^{-1}$ dry weight) showed irregular distribution of metal contamination reflecting many individual metal inputs: $\mathrm{Pb} 6.5-759.4, \mathrm{Cd} 0.8$ 4.2, $\mathrm{Cr}$ 22.6- 214.8, $\mathrm{Cu} 13.2-135.5$ and $\mathrm{Zn}$ 58.2-227.6. Metal accumulation levels in the edible muscle tissue (in $\mu \mathrm{g} \mathrm{g}$ ' wet weight) of the fish showed a wide range: $\mathrm{Pb}, 0.01-24.1, \mathrm{Cd}$, not detected - $0.3, \mathrm{Cr}, 0.01-0.4, \mathrm{Cu}, 0.1-37.7$, and $\mathrm{Zn}, 2.5-18.5$. The levels of $\mathrm{Pb}$ in edible muscle of the fish collected from W eras Ganga and Bolgoda Ganga and the level of Cd in the fish from Weras Ganga exceeded the food safety limits specified by the international authorities. Accumulation of metal levels in the liver tissues of the fish was significantly higher than that in the muscle tissue. In the gill tissue, no consistent tissue specific pattern was evident in relation to the accumulated metal levels. The results revealed that $\mathrm{Pb}$ and $\mathrm{Cd}$ are accumulating in the fish tissues at alarming levels. Accumulated $\mathrm{Cd}, \mathrm{Cu}$ and $\mathrm{Zn}$ levels in the fish collected from Weras Ganga are comparatively higher than the respective levels in the fish from South Lake. The results emphasize the importance of monitoring heavy metals in the food fish species in Bolgoda Lake regularly for the safety of fish consumers.
\end{abstract}




\section{Introduction}

Inland water bodies located in the urban areas in Sri Lanka are increasingly polluted with contaminants especially heavy metals coming through industrial waste, automobile waste and human waste. Heavy metal contaminations in inland waterbodies can be monitored by measuring the metal levels in water, sediments and resident biota especially fish. The high accumulation of heavy metals in these abiotic and biotic components can lead to serious ecological consequences. Some heavy metals such as $\mathrm{Pb}$ and $\mathrm{Cd}$ are biologically non essential metals that can be toxic to biota even at very low levels. High concentrations of some essential trace metals such as $\mathrm{Cr}, \mathrm{Cu}$ and $\mathrm{Zn}$ may become toxic at concentrations exceeding the limits which are required (Wright and Welbourn 2002). Humans who consume significant amount of fish contaminated with toxic heavy metals may also be at risk. Little information is available on heavy metal levels in food fish species found in inland water bodies in Sri Lanka. The results of the limited number of studies (Wijesinghe et al. 1996; Allinson et al. 2002; Anil and Pathiratne 2002; Silva and Shimizu 2004; Witharana et al. 2005; Indrajith et al. 2006; Manage and Wijethilaka. 2006) indicate that some heavy metals are concentrating at different levels in the sampled fish.

Bolgoda Lake is a brackish water body located in the Western province of Sri Lanka. The lake is used by the local community for various purposes including fishery. The lake has two major basins called Bolgoda North Lake and Bolgoda South Lake. A stream called Bolgoda Ganga connects these two Lakes. Extreme North end of the North Lake is called W eras Ganga (Silva 1996). The Lake receives urban and industrial wastes from multiple sources. Hence the main issue arises on whether the concentrations of pollutants in the water body represent a risk to human and aquatic biota. In the present study, bioaccumulation potential of five heavy metals viz. $\mathrm{Pb}, \mathrm{Cd}, \mathrm{Cr}, \mathrm{Cu}$ and $\mathrm{Zn}$ in a resident food fish, Mystus gulio (Long-whiskered catfish, Anguluwa)in the Bolgoda Lake covering Weras Ganga, North Lake, Bolgoda Ganga and South Lake were evaluated. In addition the metal levels in the water and sediments sampled from the four main regions of the lake were determined.

\section{Materials and Methods}

\section{Sampling of water, sediments and fish}

Water and sediment samples were collected in March, 2003 from randomly selected three sub locations in each main location of the lake viz. Weras Ganga, North Lake, Bolgoda Ganga and South Lake. Water samples were taken into pre-acid washed polypropylene bottles and kept in polystyrene boxes with ice until they were transported to the laboratory. Sediment samples were taken concurrently from the bottom surface $(1-2 \mathrm{~cm}$ 
thick) using a sediment sampler in to polypropylene containers from the randomly selected three sub locations of each of the selected four main locations and kept in ice until they were brought to the laboratory. For each sub location, three sediment samples from randomly selected sites were taken and mixed before processing. The sediment samples were kept in a freezer at $-20{ }^{\circ} \mathrm{C}$ in polypropylene containers until they were processed for the chemical analysis. Samples of M. gulio (43-656 g in body weight, 17-38 $\mathrm{cm}$ in total length) were collected in March 2003 from the four main locations. They were immediately transported to the laboratory in polyethylene bags under chilled condition and kept at $-20 \mathrm{C}$ until analysis.

\section{Processing of water and sediment for metal analysis}

Water samples were filtered through $0.45 \mu \mathrm{m}$ membrane filters immediately after the samples were transported to the laboratory. The filtrate was acidified to $\mathrm{pH} 1-2$ with concentrated nitric acid and kept in a refrigerator at $4{ }^{\circ} \mathrm{C}$. Analysis of the metals viz. $\mathrm{Pb}, \mathrm{Cd}, \mathrm{Cr}, \mathrm{Cu}$, and $\mathrm{Zn}$ in water was carried out within two weeks after the date of sampling. Each sediment sample was defrosted and put into pre-acid cleaned evaporating dish and dried in an oven at about $90^{\circ} \mathrm{C}$ for more than 48 hours until a constant weight was observed. The dried sediment samples were ground using a porcelain motor and pestle and sieved through a plastic strainer (mesh size $2 \mathrm{~mm}$ ) to remove the large particles. Sediments were digested in a Kjeldahl digestion system (Kjeldatherm, KB 125) for analysis of metals as described by Cook et al. (1997).

\section{Processing of fish tissues for metal analysis}

Fish samples were allowed for thawing and the skin of the fish was removed using a plastic knife to avoid metal contamination. The muscles, gills and liver of fish were taken into pre-acid washed crucibles and they were homogenized separately. The weight of each homogenized sample was recorded. Then the samples were kept in a drying oven at $100^{\circ} \mathrm{C}$ for more than 48 hours until a constant weight was observed. The dried sample was then ground into a fine powder using a porcelain motor and a pestle. Powdered fish tissues were digested using a dry ashing procedure (Jorhem 1993). After processing, the solution was transferred into plastic tubes for the analysis.

\section{Metal analysis}

Concentrations of $\mathrm{Pb}, \mathrm{Cd}, \mathrm{Cr}, \mathrm{Cu}$ and $\mathrm{Zn}$ in the acidified filtrate of water samples were determined using furnace atomic absorption spectrometry. The GBC mode 932 plus atomic absorption spectrometer equipped with a graphite furnace 3000 system and PAL 3000 auto sampler was used for determinations. Matrix modifiers $\left[\mathrm{Mg}(\mathrm{NQ})_{2}\right.$ or $\mathrm{Mg}\left(\mathrm{NO}_{3}\right)_{2}$ and $\left.\mathrm{NH}_{4} \mathrm{H}_{2} \mathrm{PO}_{4}\right]$ were used to eliminate matrix interferences. The metals in the sediments were analyzed by flame atomic absorption spectrometry. The analysis of metals in fish tissues were carried out by both; furnace atomic 
absorption spectrometry and flame atomic absorption spectrometry. Metals in the samples were determined using standard addition method. All the samples were analyzed in triplicates, and the mean of each value was taken. The blank determinations in triplicates were also run in the same manner during the analysis. Recovery studies were performed by spiking tissue and sediment samples with suitable aliquots of each heavy metal standards in triplicate. Recoveries ranged from $86 \%$ to $105 \%$.

\section{Statistical analysis}

Data are presented as mean \pm SEM of number of replicates. Sampling location and metal type differences were statistically tested by one way analysis of variance (ANOV A). Mean values were compared by Tukey's test. Students' $t$ test was also used in situations where appropriate. Log transformed data $(\log (\mathrm{x}+1))$ were employed for all the statistical analysis. Data were considered statistically significant when $p \leq 0.05$ (Zar 1996).

\section{Results}

\section{Metal levels in water}

Levels of dissolved metals in water sampled from four main locations of Bolgoda Lake are presented in Table 1. No significant location-related differences were seen with respect to the levels of $\mathrm{Pb}$ and $\mathrm{Cd}$ in water. The dissolved $\mathrm{Cr}, \mathrm{Cu}$ and $\mathrm{Zn}$ levels in water of four locations of the Bolgoda Lake followed the order: Cr, Bolgoda Ganga $>$ North Lake W eras Ganga $\approx$ South Lake; $\mathrm{Cu}, \mathrm{W}$ eras Ganga $>$ North Lake $\approx$ Bolgoda Ganga $\approx$ South Lake ; Zn, Weras Ganga $\approx$ North Lake $\approx$ South Lake, Weras Ganga $>$ Bolgoda Ganga. Of the five metals monitored, $\mathrm{Zn}$ and $\mathrm{Pb}$ were the most abundant metals in the lake water.

\section{Metal levels in sediments}

Levels of sediment bound metals in the four locations of Bolgoda Lake are presented in Table 2. Significant location specific differences in sediment bound $\mathrm{Cr}$ levels were not found. Sediment bound $\mathrm{Pb}, \mathrm{Cd}, \mathrm{Cu}$, and $\mathrm{Zn}$ in the four locations of the lake followed the order: $\mathrm{Pb}$, Bolgoda Ganga $>$ Weras Ganga $\approx$ North Lake $\approx$ South Lake; Cd, W eras Ganga $\approx$ North Lake $\approx$ South Lake; W eras Ganga > Bolgoda Ganga; Cu, Bolgoda Ganga > Weras Ganga $\approx$ North Lake $>$ South Lake, Zn, Weras Ganga $\approx$ North Lake $\approx$ Bolgoda Ganga $>$ South Lake. Of the five metals monitored, $\mathrm{Zn}, \mathrm{Pb}$ and $\mathrm{Cr}$ were the most abundant metals in the sediments.

\section{Metal levels in fish}

The levels of two non essential metals, $\mathrm{Pb}$ and $\mathrm{Cd}$ in the muscle, gills and liver tissues of $M$. gulio collected from four locations are presented in Table 3. The levels of $\mathrm{Pb}$ in the three tissues were significantly higher in fish collected from Bolgoda Ganga compared to the levels of this metal in the fish collected from the other three locations. 
Table 1. Dissolved lead, cadmium, chromium, copper and zinc levels in water $\mathrm{g} \mathrm{L}^{-1}$ ) collected from different sampling locations* of Bolgoda Lake.

\begin{tabular}{|c|c|c|c|c|c|}
\hline Location & $\mathrm{Pb}$ & $\mathrm{Cd}$ & $\mathrm{Cr}$ & $\mathrm{Cu}$ & $\mathrm{Zn}$ \\
\hline W eras Ganga & $\begin{array}{l}29.5 \pm 0.6^{\mathrm{a}} \\
(28.1-30.5)\end{array}$ & $\begin{array}{l}8.3 \pm 0.5^{\mathrm{a}} \\
(7.2-9.0)\end{array}$ & $\begin{array}{l}6.3 \pm 0.4^{\mathrm{a}} \\
(5.9-7.3)\end{array}$ & $\begin{array}{l}21.9 \pm 6.8^{\mathrm{a}} \\
(9.8-38.0)\end{array}$ & $\begin{array}{l}29.3 \pm 1.0^{\mathrm{a}} \\
(26.9-30.7)\end{array}$ \\
\hline North Lake & $\begin{array}{l}28.7 \pm 3.2^{\mathrm{a}} \\
(23.4-36.3)\end{array}$ & $\begin{array}{l}9.7 \pm 1.3^{\mathrm{a}} \\
(7.3-12.6)\end{array}$ & $\begin{array}{l}10.6 \pm 3.9^{\mathrm{a}} \\
(4.8-20.1)\end{array}$ & $\begin{array}{l}12.5 \pm 1.3^{b} \\
(9.6-14.9)\end{array}$ & $\begin{array}{l}25.3 \pm 1.8^{a b} \\
(21.0-28.4)\end{array}$ \\
\hline Bolgoda Ganga & $\begin{array}{l}30.0 \pm 3.1^{\mathrm{a}} \\
(23.2-36.3)\end{array}$ & $\begin{array}{l}10.9 \pm 0.4^{\mathrm{a}} \\
(10.1-11.9)\end{array}$ & $\begin{array}{l}32.4 \pm 11.9^{b} \\
(17.3-61.4)\end{array}$ & $\begin{array}{l}7.9 \pm 1.1^{b} \\
(5.7-10.2)\end{array}$ & $\begin{array}{l}15.6 \pm 1.8^{b} \\
(11.6-19.3)\end{array}$ \\
\hline South Lake & $\begin{array}{l}32.7 \pm 0.8^{\mathrm{a}} \\
(30.7-34.0)\end{array}$ & $\begin{array}{l}7.7 \pm 0.7^{a} \\
(6.1-8.8)\end{array}$ & $\begin{array}{l}5.1 \pm 0.5^{\mathrm{a}} \\
(3.9-6.2)\end{array}$ & $\begin{array}{l}13.5 \pm 1.2^{b} \\
(10.7-15.2)\end{array}$ & $\begin{array}{l}25.0 \pm 4.1^{\mathrm{ab}} \\
(19.3-35.1)\end{array}$ \\
\hline
\end{tabular}

* Metal levels for each location are presented as mean + SEM and ranges, $n=3$ sampling sites. For each column, data not followed by the same superscript are significantly different from each other (ANOV A, Tukey's test, $\mathrm{p}<0.05$ ). Log transformed data $\{\log (\mathrm{x}+1)\}$ were used for the statistical analysis 
Table 2. Levels of lead, cadmium, chromium, copper and zinc in sediments $\mu \mathrm{g} \mathrm{g}^{-1}$ dry weight) collected from different sampling locations* of Bolgoda Lake.

\begin{tabular}{|c|c|c|c|c|c|}
\hline Location & $\mathrm{Pb}$ & $\mathrm{Cd}$ & $\mathrm{Cr}$ & $\mathrm{Cu}$ & $\mathrm{Zn}$ \\
\hline W eras Ganga & $\begin{array}{l}45.7 \pm 9.7^{\mathrm{a}} \\
(26.4-67.9)\end{array}$ & $\begin{array}{l}3.1 \pm 0.5^{\mathrm{a}} \\
(2.4-4.2)\end{array}$ & $\begin{array}{l}36.1 \pm 8.6^{\mathrm{a}} \\
(22.6-56.8)\end{array}$ & $\begin{array}{l}34.5 \pm 1.4^{\mathrm{a}} \\
(32.5-37.9)\end{array}$ & $\begin{array}{l}160.3 \pm 29.0^{\mathrm{a}} \\
(89.5-200.8)\end{array}$ \\
\hline North Lake & $\begin{array}{l}36.8 \pm 4.4^{\mathrm{a}} \\
(26.4-44.1)\end{array}$ & $\begin{array}{l}2.3 \pm 0.1^{\mathrm{ab}} \\
(2.2-2.4)\end{array}$ & $\begin{array}{l}109.5 \pm 21.5^{\mathrm{a}} \\
(79.3-162)\end{array}$ & $\begin{array}{l}33.8 \pm 1.6^{\mathrm{a}} \\
(31.6-37.6)\end{array}$ & $\begin{array}{l}130.6 \pm 7.2^{\mathrm{a}} \\
(121.1-148.2)\end{array}$ \\
\hline Bolgoda Ganga & $\begin{array}{l}294 \pm 190^{b} \\
(44.1-759)\end{array}$ & $\begin{array}{l}0.8 \pm 0.02^{b} \\
(0.8-0.9)\end{array}$ & $\begin{array}{l}96.0 \pm 22.6^{\mathrm{a}} \\
(51.0-146.3)\end{array}$ & $\begin{array}{l}68.6 \pm 27.6^{b} \\
(27.2-135.5)\end{array}$ & $\begin{array}{l}189.2 \pm 26.3^{\mathrm{a}} \\
(125.2-227.6)\end{array}$ \\
\hline South Lake & $\begin{array}{l}26.5 \pm 11.7^{\mathrm{a}} \\
(6.5-54.2)\end{array}$ & $\begin{array}{l}1.9 \pm 0.4^{\mathrm{ab}} \\
(0.8-2.5)\end{array}$ & $\begin{array}{l}119.7 \pm 40.9^{\mathrm{a}} \\
(45.2-214.8)\end{array}$ & $\begin{array}{l}13.4 \pm 0.1^{\mathrm{c}} \\
(13.2-13.6)\end{array}$ & $\begin{array}{l}61.8 \pm 1.8^{b} \\
(58.2-65.7)\end{array}$ \\
\hline
\end{tabular}

* Metal levels for each location are presented as mean \pm SEM and ranges, $n=3$ (mixed samples composed of three grab samples). For each column, data not followed by the same superscript are significantly different from each other (ANOV A, Tukey's test, $\mathrm{p}<0.05$ ). $\log$ transformed data $\{\log (\mathrm{x}+1)\}$ were used for the statistical analysis. 
Table 3. Levels of lead and cadmium ( $\mathrm{ug} \mathrm{g}^{-1}$ wet weight) in muscle, gill and liver tissues of Mystus gulio collected from four locations of Bolgoda Lake.

\begin{tabular}{|c|c|c|c|c|}
\hline Metal & Location & Muscle & Gills & Liver \\
\hline $\mathrm{Pb}$ & W eras Ganga & $\begin{array}{c}\mathbf{0 . 2} \pm 0.02^{\mathrm{a} 1} \\
(0.1-0.3)\end{array}$ & $\begin{array}{c}\mathbf{0 . 4} \pm 0.04^{\mathrm{a} 12} \\
(0.3-0.5)\end{array}$ & $\begin{array}{l}\mathbf{0 . 8} \pm 0.4^{\mathrm{a} 2} \\
(0.2-2.7)\end{array}$ \\
\hline \multirow{7}{*}{$\mathrm{Cd}$} & North Lake & $\begin{array}{c}0.1 \pm 0.02^{\mathrm{a} 1} \\
\quad(0.04-0.3)\end{array}$ & $\begin{array}{c}\mathbf{0 . 2} \pm 0.02^{\mathrm{a} 1} \\
(0.1-0.3)\end{array}$ & $\begin{array}{l}\mathbf{1 . 0} \pm 0.3^{\mathrm{a} 2} \\
(0.5-2.5)\end{array}$ \\
\hline & Bolgoda Ganga & $\begin{array}{c}3.0 \pm 0.07^{b 1} \\
(0.1-24.1)\end{array}$ & $\begin{array}{c}6.6 \pm 3.4^{\mathrm{b} 12} \\
(0.8-25)\end{array}$ & $\begin{array}{c}14.7 \pm 1.6^{\mathrm{b} 2} \\
(0.5-83.7)\end{array}$ \\
\hline & South Lake & $\begin{array}{c}0.1 \pm 0.03^{\mathrm{a} 1} \\
(0.01-0.4)\end{array}$ & $\begin{array}{l}\mathbf{0 . 3} \pm 0.1^{\mathrm{a} 1} \\
(0.1-0.6)\end{array}$ & $\begin{array}{l}\mathbf{1 . 1} \pm 0.1^{\mathrm{a} 2} \\
(1.0-1.6)\end{array}$ \\
\hline & W eras Ganga & $\begin{array}{c}\mathbf{0 . 1} \pm 0.01^{\mathrm{a} 1} \\
(0.01-0.3)\end{array}$ & $\begin{array}{l}1.1 \pm 0.4^{\mathrm{a} 1} \\
(0.3-3.3)\end{array}$ & $\begin{array}{l}2.9 \pm 0.2^{\mathrm{a} 2} \\
(0.6-6.2)\end{array}$ \\
\hline & North Lake & $\begin{array}{c}0.02 \pm 0.002^{\mathrm{b} 1} \\
(0.01-0.04)\end{array}$ & $\begin{array}{l}0.023 \pm 0.002^{\mathrm{b} 1} \\
(0.02-0.04)\end{array}$ & $\begin{array}{c}\mathbf{0 . 2} \pm 0.01^{\mathrm{b} 2} \\
(0.2-0.3)\end{array}$ \\
\hline & Bolgoda Ganga & $\begin{array}{c}0.02 \pm 0.002^{\mathrm{b} 1} \\
(0.01-0.03)\end{array}$ & $\begin{array}{l}0.02 \pm 0.002^{\mathrm{b} 1} \\
(0.01-0.03)\end{array}$ & $\begin{array}{c}\mathbf{0 . 4} \pm 0.1^{b 2} \\
(0.1-0.5)\end{array}$ \\
\hline & South Lake & $\begin{array}{l}\text { Below } \\
\text { detection }\end{array}$ & $\begin{array}{l}0.03 \pm 0.001^{\mathrm{b} 1} \\
(0.02-0.04)\end{array}$ & $\begin{array}{c}\mathbf{0 . 3} \pm 0.05^{\mathrm{b} 2} \\
(0.04-2.9)\end{array}$ \\
\hline
\end{tabular}

*Metal levels are presented as mean \pm SEM and ranges, $n=15$. In a column, for a specific metal, data with no common superscript letters are significantly different. In a row, data with no common superscript numerals are significantly different (ANOV A, Tukey's test, or Students' t test where appropriate, $\mathrm{p} \leq 0.05)$. Log transformed data $\{\log (\mathrm{x}+1)\}$ were used for the statistical analysis. Means in bold faces exceeded the EU maximum allowable limits $\left(\mathrm{Pb} 0.2 \mu \mathrm{g} \mathrm{g}^{-1}, \mathrm{Cd} 0.05 \mu \mathrm{g} \mathrm{g}^{-1}\right)$. 
Table 4. Levels of chromium, copper and zinc $\left(\mathrm{ug} \mathrm{g}^{-1}\right.$ wet weight) in muscle, gill and liver tissues of Mystus gulio collected from four main locations of Bolgoda Lake.

\begin{tabular}{|c|c|c|c|c|}
\hline Metal & Location & Muscle & Gills & Liver \\
\hline $\mathrm{Cr}$ & $\begin{array}{l}\text { W eras Ganga } \\
\text { North Lake } \\
\text { Bolgoda Ganga } \\
\text { South Lake }\end{array}$ & $\begin{array}{l}0.1 \pm 0.03^{\mathrm{a} 1} \\
(0.02-0.4) \\
0.02 \pm 0.001^{\mathrm{b} 1} \\
(0.01-0.03) \\
0.1 \pm 0.01^{\mathrm{a} 1} \\
(0.03-0.2) \\
0.1 \pm 0.01^{\mathrm{a} 1} \\
(0.1-0.2)\end{array}$ & $\begin{array}{l}0.3 \pm 0.1^{\mathrm{a} 2} \\
(0.2-0.6) \\
0.04 \pm 0.01^{\mathrm{b} 1} \\
(0.1-0.14) \\
0.3 \pm 0.1^{\mathrm{a} 12} \\
(0.1-0.5) \\
0.2 \pm 0.03^{\mathrm{a} 1} \\
(0.1-0.3)\end{array}$ & $\begin{array}{l}0.3 \pm 0.1^{\mathrm{a} 2} \\
(0.2-0.5) \\
0.1 \pm 0.02^{\mathrm{b} 2} \\
(0.01-0.14) \\
0.4 \pm 0.01^{\mathrm{a} 2} \\
(0.05-0.1) \\
0.5 \pm 0.1^{\mathrm{a} 2} \\
(0.3-0.7)\end{array}$ \\
\hline $\mathrm{Cu}$ & $\begin{array}{l}\text { W eras Ganga } \\
\text { North Lake } \\
\text { Bolgoda Ganga } \\
\text { South Lake }\end{array}$ & $\begin{array}{l}9.3 \pm 3.3^{\mathrm{a} 1} \\
(1.7-37.7) \\
4.5 \pm 0.5^{\mathrm{a} 1} \\
(0.2-6.4) \\
0.8 \pm 0.1^{\mathrm{b} 1} \\
(0.3-2.2) \\
0.8 \pm 0.1^{\mathrm{b} 1} \\
(0.1-1.2)\end{array}$ & $\begin{array}{l}13.2 \pm 1.5^{\mathrm{a} 2} \\
(7.2-64.9) \\
8.0 \pm 0.6^{\mathrm{a} 2} \\
(6.1-9.8) \\
1.1 \pm 0.3^{\mathrm{b} 1} \\
(0.3-2.4) \\
1.3 \pm 0.2^{\mathrm{b} 1} \\
(0.6-2.1)\end{array}$ & $\begin{array}{l}29.7 \pm 5.9^{\mathrm{a} 3} \\
(7.2-64.9) \\
12.2 \pm 1.7^{\mathrm{a} 3} \\
(9.0-16.1)^{\mathrm{a}} \\
7.3 \pm 1.3^{\mathrm{b} 2} \\
(4.3-12.4) \\
6.1 \pm 1.5^{\mathrm{b} 2} \\
(3.1-12.4)\end{array}$ \\
\hline $\mathrm{Zn}$ & $\begin{array}{l}\text { W eras Ganga } \\
\text { North Lake }\end{array}$ & $\begin{array}{l}11.5 \pm 1.2^{\mathrm{a} 1} \\
(5-18.5) \\
\quad \text { not done } \\
\\
7.8 \pm 0.9^{\mathrm{ab} 1} \\
(3.4-12.7) \\
5.9 \pm 0.6^{\mathrm{b} 1} \\
(2.5-8.9)\end{array}$ & $\begin{array}{c}1,103 \pm 143^{\mathrm{a} 2} \\
(745-1833) \\
143 \pm 17^{\mathrm{bc} 1} \\
(93-201) \\
383 \pm 80^{\mathrm{b} 2} \\
(154-607) \\
103 \pm 6^{\mathrm{c} 2} \\
(82-123)\end{array}$ & $\begin{array}{l}1,054 \pm 108^{\mathrm{a} 2} \\
(730-1358) \\
1,903 \pm 392^{\mathrm{a} 2} \\
(983-3139) \\
42,76 \pm 438^{\mathrm{b} 3} \\
(2706-6227) \\
1,062 \pm 366^{\mathrm{a} 3} \\
(142-2041)\end{array}$ \\
\hline
\end{tabular}

*Metal levels are presented as mean \pm SEM and ranges, $n=15$. In a column, for a specific metal, data with no common superscript letters are significantly different. In a row, data with no common superscript numeral are significantly different (ANOV A, Tukey's test, or Students' t test where appropriate, $\mathrm{p} \leq 0.05)$. Log transformed data $\{\log (\mathrm{x}+1)\}$ were used for the statistical analysis. 
The tissues of the fish collected from Weras Ganga had the highest cadmium content where as the level of $\mathrm{Cd}$ in the muscle of fish sampled from South Lake was below the detection limit. Cd levels in the gills and liver tissues of fish collected from South Lake was significantly not different from those of fish collected from Bolgoda Ganga and North Lake. Location-wise comparison showed that the levels of $\mathrm{Pb}$ and $\mathrm{Cd}$ in the tissues of $\mathrm{M}$. gulio collected from Bolgoda Lake followed the order: Pb, Bolgoda Ganga > Weras Ganga $\approx$ North Lake $\approx$ South Lake; and Cd, Weras Ganga $>$ North Lake $\approx$ Bolgoda Ganga $>$ South Lake. Tissue specific comparison of the accumulation of $\mathrm{Pb}$ and $\mathrm{Cd}$ showed that the metal concentrations were significantly high in the liver tissues compared to the muscle tissues. The levels of $\mathrm{Cd}$ in the gills were not significantly different from the levels in the muscle tissues. In the fish collected from W eras Ganga and Bolgoda Ganga, $\mathrm{Pb}$ levels in the gill tissues were significantly higher than those in the muscle tissues.

The levels of three essential metals, $\mathrm{Cr}, \mathrm{Cu}$, and $\mathrm{Zn}$ in the muscle, gills and liver tissues of the fish collected at each main location are presented in Table 4. The levels of $\mathrm{Cr}$ in the three tissues of the fish collected from North Lake were significantly lower than that of the fish in the other locations. The levels of copper in the three tissues of the fish from Weras Ganga and North Lake were significantly higher compared to those in the fish collected from Bolgoda Ganga and South Lake. Zinc levels in the three tissues were higher in the fish collected from W eras Ganga compared to the fish from South Lake. Location-wise comparison showed that the levels of $\mathrm{Cr}, \mathrm{Cu}$ and $\mathrm{Zn}$ in the three tissues of $M$. gulio collected from Bolgoda Lake followed the order: $\mathrm{Cr}$, Weras Ganga $\approx$ South Lake $\approx$ Bolgoda Ganga $>$ North Lake, $\mathrm{Cu}$ W eras Ganga $\approx$ North Lake $>$ Bolgoda Ganga $\approx$ South Lake ; Zn, Weras Ganga $>$ South Lake, Bolgoda Ganga $\approx$ South Lake. Tissue specific comparison of the accumulation of metals showed that the concentrations of three metals in the liver tissues were significantly higher compared to those in the muscle tissues. The levels of $\mathrm{Cr}, \mathrm{Cu}$ and $\mathrm{Zn}$ in the gill tissue were also significantly higher than those in the muscle tissues in most of the occasions.

\section{Discussion}

Fish are considered as biomonitors of aquatic ecosystems for estimation of heavy metal pollution and risk potential for human consumption (Yilmaz et al. 2006; Agarwal et al. 2007). In the present study, accumulated levels of $\mathrm{Pb}, \mathrm{Cd}, \mathrm{Cr}, \mathrm{Cu}$ and $\mathrm{Zn}$ in different tissues inM. gulio, a food fish inhabiting in Bolgoda Lake reflect the bioavalable metal pollution in the lake. M. gulio is considered as a detritivore and a carnivore (Pethiagoda 1991). Accumulation of metals in different fish species also depends on their feeding habits, ecological needs, metabolism, age and size of the fish (Peakall and Burger 2003; Marcovecchio 2004). Observed wide ranges of specific metal levels detected in the fish collected from four locations of the lake 
may indicate that these fish had been exposed to a mixture of metals with different bioavailabilities within the lake through water and food items.

The levels of measured metals in the water samples collected from different locations of Bolgoda Lake indicate relatively high concentrations of $\mathrm{Pb}, \mathrm{Cd}$ and $\mathrm{Cu}$ exceeding Criterian Continuous Concentration (CCC: $\mathrm{Pb} 2.5$, $\mathrm{Cd} 2.2, \mathrm{Cu} 9 \mu \mathrm{g} \mathrm{L}^{-1}$ ), a water quality criterian established by USEPA for measuring water quality (USEPA 1999). Concentration of $\mathrm{Zn}$ in the lake water was below the $\mathrm{CCC}$ for $\mathrm{Zn}\left(120 \mu \mathrm{g} \mathrm{L}^{-1}\right)$ where as $\mathrm{Cr}$ concentration in Bolgoda Ganga exceeded the CCC for $\mathrm{Cr}\left(11 \mu \mathrm{g} \mathrm{L}^{-1}\right)$. Concentrations of $\mathrm{Cr}$, $\mathrm{Cu}$ and $\mathrm{Zn}$ in water differed significantly among sampling locations. The concentration of $\mathrm{Cr}$ in water was comparatively high in Bolgoda Ganga where as $\mathrm{Cu}$ concentration in water was high in Weras Ganga. The results indicate that more $\mathrm{Cr}$ and $\mathrm{Cu}$ adding sources are present near the vicinity of Bolgoda Ganga and Weras Ganga respectively.

The safety limits of different metals recommended to protect the fish in intensive aquaculture are $\mathrm{Pb}<20 \mu \mathrm{g} \mathrm{L} \mathrm{L}^{-1}, \mathrm{Cd}<0.5 \mu \mathrm{g} \mathrm{\textrm {L } ^ { - 1 }}$ in soft water, $\mathrm{Cd}$ $<5 \mu \mathrm{g} \mathrm{L}^{-1}$ in hard water, $\mathrm{Cu}<0.6 \mu \mathrm{g} \mathrm{L}^{-1}$ in soft water, $\mathrm{Cu}<30 \mu \mathrm{g} \mathrm{L}^{-1}$ in hard water and $\mathrm{Zn}<5 \mu \mathrm{g} \mathrm{L}^{-1}$ (Wedemeyer 1996). The mean levels of $\mathrm{Pb}, \mathrm{Cd}$ and $\mathrm{Zn}$ found in water of all locations exceeded the two limits. Only the water in sub location of Weras Ganga exceeded the limit for $\mathrm{Cu}$ in hard water. However, the $\mathrm{Cu}$ levels in water exceeded the limit for $\mathrm{Cu}$ under soft condition in all the locations. This situation may pose a health risk for the fish populations in Bolgoda Lake.

The present study revealed that the contents of $\mathrm{Pb}$ and $\mathrm{Cu}$ in the sediments of Bolgoda Ganga were comparatively high when compared to the metal contents in the other locations. The sediment bound $\mathrm{Cd}$ level was the highest in a sub location of W eras Ganga $\left(4.2 \mu \mathrm{g} \mathrm{g}^{-1}\right)$ and the sediment bound chromium level was the highest in a sub location of South Lake (214.8 $\mathrm{gg}$ $\left.\mathrm{g}^{-1}\right)$. No reference values of background levels for metals in sediments in inland water bodies in Sri Lanka are available. Probable effect concentrations of sediment metal levels ( $\mathrm{Pb} \mathrm{128,} \mathrm{Cd} \mathrm{5,} \mathrm{Cr} \mathrm{111,} \mathrm{Cu} \mathrm{149,} \mathrm{Zn}$ $459 \mu \mathrm{g} \mathrm{g}^{-1}$ ) have been proposed by McDonald et al. (2000). However the results of the present study show that the levels of $\mathrm{Cd}, \mathrm{Cu}, \mathrm{Zn}$ were much below the proposed probable effect concentrations of sediment levels. However, $\mathrm{Pb}$ levels in Bolgoda Ganga and $\mathrm{Cr}$ levels in several sub locations in North Lake, Bolgoda Ganga, and South Lake, exceeded these probable effect concentrations. These levels may adversely affect the sediment dwelling organisms in the Lake.

Lead and cadmium are non essential elements which are accumulated in human tissues and harmful to human health. Location-specific comparison of the five metals in $M$. gulio revealed that $\mathrm{Pb}$ and $\mathrm{Cd}$ levels in different tissues of the fish collected from Weras Ganga and Bolgoda Ganga are comparatively higher than the respective levels in the fish from South Lake. Hence, there are more $\mathrm{Pb}$ and $\mathrm{Cd}$ adding sources especially in W eras Ganga and Bolgoda Ganga compared to South Lake. The level of $\mathrm{Pb}$ in the edible 
muscle of $M$. gulio collected from Bolgoda Lake ranged from $0.0124 .1 \mu \mathrm{g}$ $\mathrm{g}^{-1}$ wet weight where as the level of $\mathrm{Cd}$ in the muscle ranged from below the detection limit to $-0.3 \mu \mathrm{g} \mathrm{g}^{-1}$ wet weight. The maximum allowable levels of lead and cadmium in the fish for human consumption specified by the European Union are 0.2 and $0.05 \mu \mathrm{g} \mathrm{g}^{-1}$ wet weight respectively (EU 2002). Of the different metal levels detected in the edible muscle of . gulio the level of $\mathrm{Pb}$ in the fish from W eras Ganga and Bolgoda Ganga and the level of $\mathrm{Cd}$ in the fish from Weras Ganga exceeded the maximum levels in fish for human consumption specified by European Union. The maximum levels of lead and cadmium in food fish specified by the EU are lower than the other international standards for food. According to the median international standards for food, the tolerable levels for lead and cadmium in food are 2 and $0.3 \mu \mathrm{g} \mathrm{g}^{-1}$ wet weight respectively (Philips 1993). Lead levels in the muscle tissue of the fish collected from Bolgoda Ganga exceeded this international standard for lead. Cadmium levels in some fish from $\mathrm{W}$ eras Ganga exceeded the international standard for cadmium in food. Hence, heavy consumption of $M$. gulio especially from W eras Ganga and Bolgoda Ganga may pose a health risk for fish consumers.

Chromium, Copper and Zinc are essential elements and are regulated by physiological mechanisms in most organisms. However, occurrence of excessive levels of them is regarded as potential hazards which can endanger both animal and human health (Wright and Welbourn 2002). The level of chromium in the edible muscle ofM. gulio collected from Bolgoda Lake ranged from $0.01-0.4 \mu \mathrm{g} \mathrm{g}^{-1}$ wet weight. The levels of $\mathrm{Cr}$ in the muscle were lower than the median international standards $\left(1 \mu \mathrm{g} \mathrm{g} \mathrm{g}^{-1}\right.$ wet weight $)$ of chromium in food (Philips 1993). The levels of $\mathrm{Cu}$ and $\mathrm{Zn}$ in the edible muscle of $M$. gulio collected from Bolgoda Lake ranged from 0. 1-37.7 and 0.5-18.5 $\mu \mathrm{g} \mathrm{g}^{-1}$ wet weight respectively. The median international standard levels of copper and zinc in the food for human consumption are 20 and 45 $\mu \mathrm{g} \mathrm{g}^{-1}$ wet weight respectively (Philips 1993). The levels of $\mathrm{Cu}$ in the edible muscle of some fish from Weras Ganga exceeded this limit. The levels of $\mathrm{Zn}$ in the edible muscle of $M$. gulio collected from all locations of Bolgoda Lake were lower than these median international standard levels. Hence, $\mathrm{Zn}$ levels have posed no threat for consumption of the fish muscle from the lake. However liver tissues of the fish collected from the lake exceeded these standards for $\mathrm{Pb}, \mathrm{Cd}, \mathrm{Cu}$, and $\mathrm{Zn}$.

The levels of selected five metals detected in muscle, gills and liver tissues of $M$. gulio from Bolgoda Lake showed different capacities for metal accumulation. In general the metal accumulation was found to be very high in the liver in comparison to the muscle tissues of the fish. Metal levels in liver reflect the high metal storage capacity of the organ. Heavy metals accumulate mainly in metabolic organs such as liver that stores metals by producing metallothioneins which appears as a metal detoxification mechanism within the body (Roesijadi and Robinson 1994; Peakall and Burger 2003). Metallothioneins are a family of low molecular weight cystein 
rich proteins that have been reported in vertebrates and several invertebrates. Their synthesis can be induced by a wide variety of metal ions including cadmium, copper, and zinc. Hence metallothioneins have been proposed as biomarkers to indicate the presence of high levels of metals in the environment (Peakall and Burger 2003). In the present study, gill tissues of the fish collected from several occasions also had high metal contents comparable to liver tissues where as in the other occasions the metal contents in gills were not significantly different from the levels in the muscle tissue. In general the concentrations of metals in the gills may reflect the concentration of metals in water. Metal concentrations in the gills could also be due to complexing of the elements with mucus remaining between the gill lamella, which is hard to remove completely from the gills before preparation of the tissue for analysis (Demirak et al. 2005). The accumulation of metals in gills and liver of food fish do not directly affect human health because these are not edible parts. Nevertheless the predatory animals such as birds who consume the whole fish from the lake are at risk of excess metal contamination.

In earlier studies, relatively high levels of some heavy metals have been detected in tilapia,Oreochromis mossambicus inhabiting Weras Ganga and Bolgoda lagoon area (Wijesinghe et al. 1996; Anil and Pathiratne 2002). A more recent study on accumulation pattern of selected heavy metals in some edible fish species from Panadura estuary and Horethuduwa detected high bioaccumulation factors for $\mathrm{Cd}, \mathrm{Cr}, \mathrm{Cu}$ in plankton from Panadura estuary and $\mathrm{Zn}$ in a food fish, Netuma thalassinus (Manage and Wijethilaka 2006). The present study also revealed potential for accumulation of $\mathrm{Pb}, \mathrm{Cd}$, $\mathrm{Cr}, \mathrm{Cu}$ and $\mathrm{Zn}$ in different tissues of $\mathrm{g}$. gulio, a food fish in Bolgoda Lake.

In conclusion, the levels of $\mathrm{Pb}$ in edible muscle of the fish collected from Weras Ganga and Bolgoda Ganga and the level of $\mathrm{Cd}$ in the fish from Weras Ganga exceeded the food safety limits specified by the international authorities. The results showed that, heavy consumption of $M$. gulio from Bolgoda Lake especially from Weras Ganga and Bolgoda Ganga may pose a health risk to the consumers due to accumulation of high levels of lead and cadmium. Comparison of metal levels in different tissues of $M$. gulio inhabiting Bolgoda Lake indicates that accumulation of metal levels in the liver tissues of the fish was significantly higher than that in the muscle tissue. However, no consistent pattern was evident in relation to the accumulated metal levels in the gill tissue compared to the liver and muscle tissues of the fish collected from different locations. Location-specific comparison of the five metals in the fish revealed that accumulated $\mathrm{Cd}, \mathrm{Cu}$ and $\mathrm{Zn}$ levels in the fish collected from Weras Ganga were comparatively higher than the respective levels in the fish from South Lake. As Bolgoda Lake continuously receives urban and industrial wastes from multiple sources, it is very important to monitor heavy metals in the food fish species in Bolgoda Lake regularly for the safety of fish consumers. 


\section{References}

Agarwal, R, R. Kumar \& J. R. Behari 2007.

Mercury and lead content in fish species from the river Gomti, lucknow, India as biomarkers of contamination. Bulletin of Environmental contamination and Toxicology 78;108-112

Allinson, G, M. Nishikawa, S. S. De Silva, L. J. B. Laurenson \& K. De. Silva 2002.

Observations on metal concentration in tilapia Oreochromis mossambicus) in reservoirs of South Sri Lanka. Ecotoxicology and Environmental Safety 51:197-202

Anil, K. A \& A. Pathiratne 2002.

Accumulation of lead, cadmium and copper in food fish, Oreochromis mossambicus from Bolgoda Lagoon and Beira Lake, Sri Lanka. Sri Lanka Journal of Aquatic Sciences 7:75-83

Cook, J.M, M. J. Gardner, A. H. Griffiths, M. A. Jessep, J. E. Ravenscroft \& R.Yates 1997.

The comparability of sample digestion techniques for the determination of metals in sediments. Marine Pollution Bulletin, 34( 8): 637-644.

Demirak, A, F. Yilmaz, A. L. Tuna, N. Ozdemir 2005.

Heavy metals in water, sediment and tissues ofLeuciscus cephalus

from a stream in Southwestern Turkey. Chemosphere doi;10.1016/j.chemosphere.2005.09.033

EU, 2002.

The Commission of the European Communities, Commission regulation, (EC) No. 221/2002 amending regulation (EC) No. $466 / 2001$ setting maximum levels for certain contaminants in food stuff in order to protect public health. Official Journal of the European Communities 7.2.2002, L37/5-L37/6

Indrajith, H. A. P, K. A. S. Pathiratne \& A. Pathiratne 2006.

Heavy metal levels in two species of food fish,Etroplus suratensis and Ambassis commersoni inhabiting in Negombo lagoon, Sri Lanka. Proceedings of the $62^{\text {nd }}$ annual sessions of the Sri Lanka Association for the Advancement of Science Part I, 84

Jorhem, L 1993.

Determination of metals in foodstuffs by atomic absorption spectrometry after dry ashing: NMKL interlaboratory study of lead, cadmium, zinc, copper, iron, chromium and nickel. Journal of AOAC International 76:798-815

McDonald, D.D, C. G. Ingersoll \& T. A. Berger 2000.

Development and evaluation of consensus based sediment quality guidelines for freshwater ecosystems. Archives of Environmental Contamination and Toxicology 39: 20-31.

Manage, P.M \& S. D. Wijethilaka 2006. 
Accumulation pattern of some selected heavy metals in some edible fish species from Bolgoda lagoon. Proceedings of the $62^{\text {hd }}$ annual sessions of the Sri Lanka Association for the Advancement of Science Part I, 83.

Marcovecchio, J. E. 2004.

The use of Micropogonias furnieri and Mugil liza as bioindicators of heavy metal pollution in La Plata river estuary, Argentina. Science of the Total Environment 323:219-226

Peakall, D \& J. Burger 2003.

Methodologies for assessing exposure to metals: speciation, bioavailability of metals \& ecological host factors: Ecotoxicology and Environmental Safety 56:110-121

Pethiagoda, R 1991.

Freshwater Fishes of Sri Lanka. Wildlife Heritage Trust of Sri Lanka Philips, D. J. H 1993.

Developing country aquaculture - trace chemicals contaminants and public health concerns. In :Environment and Aquaculture in Developing Countries. (R. S. V.Pullin, H. Rosenthal and J. L Maclean. eds.) Vol. 31, pp.296-311. ICLARM Conference Proceedings.

Ploetz, D. M., B. E. Fitts \& T. M. Rice 2007.

Differential accumulation of heavy metals in muscle and liver of a marine fish (King Mackeral, Scomberomorus cavalla, Cuvier) from the Northen Gulf of Maxico, USA. Bulletin of Environmental Contamination and Toxicology 78:124-128.

Roesijadi, G \& W. E. Robinson 1994.

Metal regulation in aquatic animals: mechanisms of uptake, accumulation and release. In : Aquatic Toxicology: Molecular, Biochemical and Cellular Perspectives. (D. C. Malins and G. K. Ostrander eds.) Lewis Publishers, pp. 387-420

Silva, E. I. L. 1996.

Water Quality of Sri Lanka - A Review on Twelve Water Bodies : Institute of Fundamental Studies, Kandy

Silva, E. I. L. \& A. Shimizu 2004.

Concentration of trace metals in the flesh of nine fish species found in a Hydropower reservoir in Sri Lanka. Asian Fisheries Science 17:377-384

USEPA, (United States Environmental Protection Agency) 1999.

National recommended water quality criteria - Correction EPA 822/Z-99.001, USEPA, Washington DC.

W edemeyer, A.G., 1996.

Physiology of Fish in Intensive Culture Systems. Chapman \& Hall, New York.

Wijesinghe, M. R, Y. N. A. Jayatunga \& R. Hewamanna 1996. 
Bioaccumulation of heavy metals in Oreochromis mossambicus. Proceedings of the $52^{\text {nd }}$ annual sessions of the Sri Lanka Association for the Advancement of Sciences, Part I, 153-154.

Witharana, W. A. U., N. J. G. J. Bandara \& S. Piyasiri 2005.

Investigation of heavy metals in edible fish species in a section of Bellanwila-Attidiya canal . Proceedings of the Sri Lanka Association for the Advancement of Sciences, $61^{\mathrm{t}}$ annual sessions, Part I abstract 43.

Wright, D. A \& P. Welbourne 2002.

Environmental Toxicology, Cambridge University press.

Yilmaz, F, N. Özdemir, A. Demirah, \& A. L. Tuna 2006

Heavy metal levels in two fish species:Leuciscus cephalus and Lepomis gibbosus. Food Chemistry doi:10.1016/j.foodchem.2005.09.020

Zar, J. H. 1996.

Biostatistical Analysis, Printice-Hall, Englewood Cliffs, N.J. 